\title{
PERBEDAAN BERPIKIR KRITIS ANTARA SISWA YANG DIAJAR DENGAN MENGGUNAKAN BAHAN AJAR LKS BERBASIS MODEL BERPIKIR INDUKTIF DAN MODEL INDUKTIF KATA BERGAMBAR PADA MATA PELAJARAN IPA KELAS IV SDM II KOTA BENGKULU
}

\author{
Sukarno dan Salamah \\ IAIN Bengkulu \\ sukarno@gmail.com
}

\begin{abstract}
This study aims to determine differences in students' critical thinking by using science-based LKS teaching materials based on inductive thinking models with Inductive Word Pictorial models in class IV SDM II of Bengkulu City, critical thinking differences from groups of students with high initial ability using teaching materials based on science-based LKS inductive thinking with the pictorial word Inductive model in class IV SDM II Bengkulu City, the difference in critical thinking from the group of students with low initial ability by using science teaching material based on inductive thinking models with the Inductive Word Pictorial model in class IV SDM II Bengkulu City, the interaction between learning model and the initial ability to think critically in class IV SDM II Bengkulu City. This study uses a quantitative approach to the type of quasi-experimental research. The subjects of this study were HR II students, totaling 40 students. Data collection was performed using essay tests. The results showed 1) Overall there were differences in students' critical thinking between those taught by using teaching materials for science subjects based on the learning model of inductive thinking and based on the pictorial model of pictorial words. . 2) there is a difference in the critical thinking of students with high initial ability between those taught by using teaching materials for science subjects based on inductive thinking learning models and based on the pictorial model of pictorial words. 3) there is no difference in the critical thinking of students with low initial ability between those taught by using teaching materials based on natural science learning models based on inductive thinking models and based on the pictorial model of pictorial words. students in science subjects at SD Muhammadiyah II Bengkulu city.
\end{abstract}

Keywords: Inductive Thinking Model, Picture Word Inductive Model, Critical Thinking.

Abstrak. Penelitian ini bertujuan Untuk mengetahui perbedaan berpikir kritis siswa dengan menggunakan bahan ajar LKS IPA berbasis model berpikir induktif dengan model Induktif Kata Bergambar pada kelas IV SDM II Kota Bengkulu, perbedaan berpikir kritis dari kelompok siswa yang berkemampuan awal tinggi dengan menggunakan bahan ajar LKS IPA berbasis model berpikir induktif dengan model Induktif Kata Bergambar pada kelas IV SDM II Kota Bengkulu, perbedaan berpikir 
kritis dari kelompok siswa yang berkemampuan awal rendah dengan menggunakan bahan ajar LKS IPA berbasis model berpikir induktif dengan model Induktif Kata Bergambar pada kelas IV SDM II Kota Bengkulu, interaksi antara model pembelajaran dan kemampuan awal terhadap berpikir kritis siswa kelas IV SDM II Kota Bengkulu. Penelitian ini menggunakan pendekatan Kuantitatif dengan jenis penelitian quasi eksperimen. Subjek penelitian ini adalah siswa SDM II yang berjumlah 40 orang siswa. Pengumpulan data dilakukan dengan menggunakan tes essay. Hasil penelitian menunjukkan 1) Secara keseluruhan terdapat perbedaan berpikir kritis siswa antara yang diajar dengan menggunakan bahan ajar LKS mata pelajaran IPA berbasis model pembelajaran berpikir induktif dengan berbasis model Induktif Kata Bergambar. .2) terdapat perbedaan berpikir kritis siswa yang berkemampuan awal tinggi antara yang diajar dengan menggunakan bahan ajar LKS mata pelajaran IPA berbasis model pembelajaran berpikir induktif dengan berbasis model Induktif Kata Bergambar. 3) tidak terdapat perbedaan berpikir kritis siswa yang berkemampuan awal rendah antara yang diajar dengan menggunakan bahan ajar LKS mata pelajaran IPA berbasis model pembelajaran berpikir induktif dengan berbasis model Induktif Kata Bergambar..4) Terdapat interaksi antara model pembelajaran dengan pengetahuan awal terhadap kemampuan berpikir kritis siswa pada mata pelajaran IPA di SD Muhammadiyah II kota Bengkulu.

Kata Kunci: Model Berpikir Induktif, Model Induktif Kata Bergambar, Berpikir kritis.

\section{Pendahuluan}

Dalam proses belajar mengajar ada dua unsur yang sangat penting yaitu metode mengajar dan media pengajaran, kedua aspek ini saling berkaitan terhadap kualitas pembelajaran. Kualitas pembelajaran adalah mempersoalkan bagaimana kegiatan pembelajaran yang dilakukan selama ini berjalan dengan baik serta menghasilkan luaran yang baik pula. ${ }^{1}$ Pembelajaran yang berkualitas pembelajaran yang tergantung dari motivasi pelajar atau pendidik. Pembelajaran yang motivasi tinggi ditunjang dengan pengajar yang mampu memfasilitasi motivasi tersebut akan membawa kepada keberhasilan pencapaian tujuan belajar. Kondisi pembelajran yang berkualitas dipengaruhi oleh faktor-faktor yaitu, tujuan pengajaran yang jelas, bahan pengajaran yang memadai, metodelogi pengajaran yang tepat, dan cara penilaian yang baik. Di dalam metodelogi pengajaran ada dua aspek yang paling menonjol yaitu metode mengajar dan media pengajaran, sebagai alat bantu mengajar, dimana media pengajaran ini merupakan salah satu lingkungan belajar yang dikondisikan oleh guru. ${ }^{2}$ Salah satu ciri dari pelaksanaan pembelajaran yang berkualitas adalah dimanfaatkannya media dalam proses pembelajaran. Dengan faktor-faktor pembelajaran yang

\footnotetext{
1 Hamzah. 2009. Model Pembelajaran Menciptakan Proses Belajar Mengajar yang Kreatif dan Efekti. Jakarta: Bumi Aksara. Hal.153

${ }^{2}$ Kunandar. 2009. Guru Profesional Implementasi KTSP dan Sukses dalam Sertifikasi Guru. Jakarta: PT RajaGrafindo Persada. hal.45
} 
berkualitas di atas diharapkan dapat meningkatkan kualitas pendidikan di Indonesia.

Guru yang inovatif yaitu guru yang mampu menciptakan sesuatu yang baru dalam bentuk sumber yang sesuai dengan perkembangan zaman. Guru lebih membuka diri kepada ide-ide baru, komunikasi yang terampil dan bersedia mengambil resiko.

Membimbing siswa dengan penuh keikhlasan dan kasih sayang dan menghormati pendapat orang lain. Guru inovatif dapat mempengaruhi siswa dalam proses belajar mengajar. Maka guru harus mampu menciptakan proses belajar mengajar yang sedemikian rupa sehingga dapat membuat siswa untuk belajar aktif dan dinamis dalam memenuhi kebutuhan dan menciptakan suasana pembelajaran yang menyenangkan.

Tetapi pada kenyataannya masih ada sebagian guru yang belum memanfaatkan pembelajaran yang inovatif. Berdasarkan hasil observasi awal di SDM II Kota Bengkulu bahwa guru hampir seluruhnya sudah memenuhi tugasnya sebagai guru, bahkan sebagian besar sudah tersertifikasi sebagai pendidik, yakni hadir tepat waktu, membuat perencanaan dan meleksanakan proses pembelajaran sebagai mana tugasnya, namun dari sisi lain hampir kurang seluruh guru yang ada masih brlum memanfaatkan strategi dan metode yang inovatif.

Hal ini juga terlihat disaat pembelajaran berlangsung, guru masih cenderung secara kontibyus menggunakan metode ceramah yang tidak dilengkapi dengan media dan alat-alat lainnya, terutama dalam pembelajaranpembelajaran IPA, guru lebih sering menggunakan buku cetak yang tidak semua siswa punya. Lembar Kerja Siswa (LKS) yang ada hanya digunakan sebagai tugas anak, dan masih banyak guru tidak memperhatikan dan tidak peduli terhadap siswa yang kurang memahami materi pembelajaran, guru belum secara optimal mengambil tindakan terhadap siswa yang tidak fokus dalam proses belajar mengajar.

Di samping itu guru masih menggunakan gaya mengajar yang bersifat monopoli, sementara siswa bersifat pasif, kurang kreatif, sehingga berdampak dengan kreatifitas berpikir anak lemah, dan akhirnya hasil belajar yang dicapainya juga akan rendah yakni nilai rata-rata masih di bawah 65 .

Jika guru melakukan proses pembelajaran seperti di atas, maka proses belajar mengajar tidak sesuai dengan tujuan pembelajaran. Dalam proses belajar mengajar guru harus mengerti akan tugas-tugasnya membimbing dan mengarahkan siswanya agar giat belajar dengan cara memotivasi dan melakukan pendekatan untuk membantu siswa dalam memecahkan materi yang belum dipahaminya sehingga siswa mengerti terhadap materi pembelajaran yang disampaikan guru terutama dalam pembelajaran IPA.

Padahal pembelajaran IPA tidak hanya merupakan kumpulan pengetahuan tentang benda atau makhluk hidup, tetapi peserta didik diberi 
kesempatan untuk berlatih keterampilan-keterampilan proses IPA, sebab diharapkan mereka dapat berpikir dan memiliki sifat ilmiah.

Cara berpikir terutama berpikir kritis sangatlah diperlukan untuk mengembangkan sikap dan persepsi yang mendukung terciptanya kondisi kelas yang positif. Memperoleh dan mengintegrasikan pengetahuan, memperluas wawasan pengetahuan, dan mengaktualisasikan kebermaknaan pengetahuan.

Berpikir kritis diperlukan untuk menghadapi dunia modern dimana semua informasi disediakan secara instan. Dapat membantu siswa dalam meningkatkan pemahaman materi yang dipelajari dengan mengevaluasi secara kritis argumen pada buku teks, jurnal, teman diskusi, termasuk argumen guru dalam kegiatan pembelajaran. Agar siswa dapat menggunakan potensi pikiran secara optimal, sehingga menjadi pembaca yang cermat dan penulis yang kreatif. 4

Hal ini dikarenakan dalam penyampaian materi pelajaran, guru tidak akan mengalami kesulitan, tidak merasa terbebani, tujuan pembelajaranpun dapat kita capai dengan mudah, serta siswa akan mudah mengerti, memahami, dan mengingat materi pelajaran sehingga berpikir kritis siswa dapat berkembang.

Berdasarkan latar belakang diatas, dapat dirumuskan masalah sebagai berikut: (1) Apakah terdapat perbedaan berpikir kritis siswa dengan menggunakan bahan ajar LKS IPA berbasis model berpikir induktif dengan model Induktif Kata Bergambar pada kelas IV SDM II Kota Bengkulu? (2) Apakah terdapat perbedaan berpikir kritis dari kelompok siswa yang berkemampuan awal tinggi dengan menggunakan bahan ajar LKS IPA berbasis model berpikir induktif dengan model Induktif Kata Bergambar pada kelas IV SDM II Kota Bengkulu? (3) Apakah terdapat perbedaan berpikir kritis dari kelompok siswa yang berkemampuan awal rendah dengan menggunakan bahan ajar LKS IPA berbasis model berpikir induktif dengan model Induktif Kata Bergambar pada kelas IV SDM II Kota Bengkulu? (4) Apakah terdapat interaksi antara model pembelajaran dan kemampuan awal terhadap berpikir kritis siswa kelas IV SDM II Kota Bengkulu?

LKS merupakan alat belajar siswa yang memuat berbagai kegiatan yang akan dilaksanakan oleh siswa secara aktif. Kegiatan tersebut dapat berupa pengamatan, eksperimen, dan pengajuan pertanyaan. ${ }^{5}$ LKS dibuat bertujuan untuk menuntun siswa akan berbagai kegiatan yang perlu diberikan serta mempertimbangkan proses berpikir yang akan ditumbuhkan pada diri siswa.

\footnotetext{
${ }^{3}$ Haryono. 2013. Pembelajaran IP A yang Menarik dan Mengasyikan: Teori dan Aplikasi PAIKEM. Yogyakarta: Kepel Press. Hal.39

${ }^{4}$ Elika Dwi Murwani. 2006. Peran Guru dalam Membangun Kesadaran Kritis siswa. Jurnal Pendidikan Penabur. hal.60

5 Trianto. 2013. Desain Pengembangan Pembelajaran Tematik Bagi Anak Usia Dini TK/RA \& Anak Kelas Aal SD/MI. Jakarta: Kencana Prenada Media Group. Hal.243
} 
LKS mempunyai fungsi sebagai urutan kerja yang diberikan dalam kegiatan baik intrakurikuler maupun ekstrakurikuler terhadap pemahaman materi yang telah diberikan., termasuk dalam pembelajaran IPA SD.

Daryanto menyatakan, IPA adalah suatu kumpulan pengetahuan yang tersusun secara sistematik yang didalam penggunaannya secara umum terbatas pada gejala-gelaja alam. ${ }^{6}$ IPA pada hakikatnya dapat dipandang dari segi produk, proses dan dari segi pengembangan sikap.

IPA sebagai produk adalah dalam pembelajaran IPA seorang guru dituntut untuk dapat mengajak anak didiknya memanfaatkan alam sekitar sebagai sumber belajar. Alam sekitar merupakan sumber belajar yang paling otentik dan tidak akan habis digunakan. ${ }^{7}$ IPA sebagai proses mengandung pengertian cara berpikir dan bertindak untuk menghadapi atau merespon masalah-masalah yang ada dilingkungan. ${ }^{8}$ IPA sebagai pengembangan sikap yaitu ketika siswa melakukan diskusi, percobaan, simulasi atau kegiatan di lapangan.

Perkembangan kemampuan berpikir dikenal pula sebagai perkembangan kognitif. Perkembangan kognitif seseorang mengikuti tahap-tahap sebagai berikut.

1. Tahap pertama : Masa sensori motor $(0.0-2.5$ tahun $)$

Masa ketika bayi mempergunakan sistem pengindraan dan aktivitas motorik untuk mengenal lingkungannya. Bayi memberikan reaksi motorik atas rangsangan-rangsangan yang diterimanya dalam bentuk refleks; misalnya refleks mencari puting susu ibu, refleks menangis, dan lain-lain. Refleks-refleks inikemudian berkembang lagi menjadi gerakan-gerakan yang lebih canggih, misalnya berjalan.

2. Tahap kedua : Masa pra-operasional (2.0 - 7.0 tahun)

Ciri khas masa ini adalah kemampuan anak menggunakan simbol yang mewakili sesuatu konsep. Misalnya kata "pisau plastik". Kata "pisau" atau tulisan "pisau" sebenarnya mewakili makna benda yang sesungguhnya. Kemampuan simbolik ini memungkinkan anak melakukan tindakan-tindakan yang berkaitan dengan hal-hal yang telah lewat; misalnya seorang anak yang pernah melihat dokter berpraktek, akan (dapat) bermain "dokter-dokteran".

1. Tahap ketiga : Masa konkreto prerasional (7.0 - 11.0 tahun)

Pada tahap ini anak sudah dapat melakukan berbagai macam tugas yang konkret. Anak mulai mengembangkan tiga macam operasi berpikir, yaitu :

a) Identifikasi : mengenali sesuatu,

b) Negasi : mengingkari sesuatu, dan

\footnotetext{
${ }^{6}$ Daryanto. 2014. Pembelajaran Tematik, Terpadu, Terintegrasi (Kurikulum 2013). Yogyakarta: Gava Media. Hal.160

7 Sri Sulistyorini2007. Model Pembelajaran IPA Sekolah Dasar dan Penerapannya Dalam KTSP. Yogyakarta: Tiara Wacana. Hal.9

${ }^{8}$ Haryono. 2013. Pembelajaran IPA ynag Menarik dan Mengasyikan: Teori dan Aplikasi PAIKEM. Yogyakarta: Kepel Press. Hal.45

${ }^{9}$ Op.cit Hal.10
} 
c) Reprokasi : mencari hubungan timbal-balik antara beberapa hal.

2. Tahap keempat: Masa Operasional(11.0 - dewasa).

Dalam usia remaja dan seterusnya seseorang sudah mampu berpikir abstrak dan hipotesis. Pada tahap ini seseorang bisa memperkirakan apa yang mungkin terjadi. Ia dapat mengambil kesimpulan dari suatu pernyataan seperti: "Kalau mobil A lebih mahal dari pada mobil B, sedang mobil C lebih murah dari pada mobil B, maka ia dapat menyimpulkan mobil mana yang paling mahal dan yang mana yang paling murah." 10

Kemampuan awal (entry behavior) pada dasarnya merupakan keadaan pengetahuan atau keterampilan yang harus dimiliki terlebih dahulu oleh siswa sebelum ia mempelajari pengetahuan atau keterampilan baru ${ }^{11}$

Model berpikir induktif dapat membantu siswa mengumpulkan informasi dan mengujinya dengan teliti, mengolah informasi kedalam konsepkonsep tersebut. Digunakan secara bertahap, strategi ini juga dapat meningkatkan kemampuan siswa untuk membentuk konsep-konsep secara efisien dan meningktkan jangkauan perspektif dari sisi mana mereka memandang suatu informasi. ${ }^{12}$

Tahap-tahap model induktif tersebut meliputi:

a) Mengidentifikasikan dan menghitung data yang relevan dengan topik atau masalah.

b) Mengelompokkan objek-objek ini menjadi kategori-kategori yang anggotanya memiliki sifat umum.

c) Menafsirkan data dan mengembangkan label untuk kategori-kategori tadi sehingga data tersebut bisa dimanipulasi secara simbolis.

d) Mengubah kategori-kategori menjadi keterampilan atau hipotesishipotesis. $^{13}$

Menurut Joyce, Weil, dan Calhoun menjelaskan bahwa model induktif kata-bergambar merupakan salah satu strategi pengajaran tambahan yang sangat menarik dan luar biasa, utamanya dalam hal keluasan landasan dan penerapannya. Landasan model ini selain berdasarkan pada penelitian dalam bidang baca tulis pada umumnya bagaimana siswa mengembangkan kemampuan baca tulis (khususnya bagaimana mereka belajar membaca dan menulis), juga berdasarkan pada materi baca tulis dalam semua bidang kurikulum, sebagaimana pengembangan kognitif. Pengembangan

\footnotetext{
10 Sunarto dan Agung Hartono. 2008. Perkembangan Peserta Didik. Jakarta: Rineka Cipta. hal.23-25

11 Muhammad Ali, 2012. Guru dan Proses Belajar dan Mengajar, Bandung: Sinar Baru Algensindo Offset. Hal: 74

12 Bruce,J,Marsha,W dan Emily. 2009. Models Of Teaching. Yogyakarta: Pustaka Pelajar. hal.102

13 Opcit, hal.104
} 
metakognitif merupakan inti untuk belajar bagaimana belajar terbangun dalam suatu proses pembelajaran ${ }^{14}$

Langkah-langkah Model Pembelajaran Induktif Kata-Bergambar

a) Pilihlah sebuah gambar.

b) Mintalah siswa mengidentifikasi apa yang mereka lihat dalam gambar tersebut.

c) Tandai bagian-bagian gambar yang telah diidentifikasi tadi.

d) Membaca/mereview bagan kata bergambar.

e) Meminta siswa mengklasifikasi kata-kata ke dalam berbagai jenis kelompok.

f) Membaca/mereview bagan kata bergambar.

g) Menyuruh siswa berfikir tentang judul untuk bagan kata bergambar itu. (guru membimbing siswa untuk berpikir)

h) Menyuruh siswa menyusun sebuah kalimat, kalimat-kalimat atau suatu paragraf secara langsung yang berhubungan dengan bagan kata bergambar tadi.

i) Membaca/mereview kalimat-kalimat atau paragraf-paragraf ${ }^{15}$

Berpikir adalah merupakan aktivitas psikis yang intensional, dan terjadi apabila seseorang sedang dalam masalah yang harus dipecahkan. ${ }^{16}$ Pemikiran kritis adalah pemahaman atau refleksi terhadap permasalahan secara mendalam, mempertahankan pikiran agar tetap terbuka bagi berbagai pendekatan dan perspektif yang berbeda, tidak mempercayai begitu saja informasi-informasi yang datang dari berbagai sumber (lisan atau tulisan), dan berpikir secara reflektif dan evaluatif. ${ }^{17}$

kemampuan berpikir kritis merupakan kegiatan kognitif atau proses dan tindakan mental untuk memperoleh pengetahuan, pemahaman dan keterampilan dalam harapan yang mampu menemukan jalan keluar dan melakukan keputusan secara deduktif, induktif dan evaluatif sesuai dengan langkahnya yang dilakukan dengan berpikir secara mendalam tentang hal-hal yang dapat dicapai oleh pengalaman seseorang, inspeksi dan melakukan akal sehat logis yang diukur dengan efisiensi interpretasi melalui, analisis, asumsi pengakuan, pengurangan, inferensi evaluasi, eksplanasi / penjelasan, dan regulasi diri. ${ }^{18}$

Beberapa penelitian telah dilakukan dalam menerapkan beberapa model dalam kaitannya dengan hasil belajar IPA (1). Ida Ayu Adisti Ligianing Putri, I

\footnotetext{
14 Joyce, Marsha Weil, dan Emily Calhoun. 2009. Models Of Teaching. Yogyakarta : Pustaka Pelajar, hlm. 148

15 Joyce, Marsha Weil, dan Emily Calhoun. 2009. Models Of Teaching. Yogyakarta : Pustaka Pelajar, hlm. 165-166

16 Abu Ahmadi. 2009. Psikologi Umum. Jakarta: PT Rineka Cipta. Hal.83

17 Desmita. 2008. Psikologi Perkembangan. Bandung: PT Remaja Rosdakarya. hal.161

18 Kowiyah. 2012. Kemampuan Berpikir Kritis. Jurnal Pendidikan Dasar. hal.175
} 
Ketut Ardana, dan Ni Nyoman Ganing (2014) "Pengaruh Model Pembelajaran Induktif Berbasis Integratif Terhadap Hasil Belajar IPA Siswa Kelas v Semester I SD Gugus r.a Kartini” menyatakan bahwa berdasarkan hasil penelitian dan pembahasan dapat dikemukakan terdapat perbedaan yang signifikan hasil belajar IPA antara siswa yang dibelajarkan menggunakan model pembelajaran induktif berbasis integratif dengan siswa yang dibelajarkan menggunakan pembelajaran konvensional. (2) Kowiyah (2012) yang berjudul "Kemampuan Berpikir Kritis". Menyatakan bahwa sarana lain yang dapat digunakan untuk melatih siswa berpikir kritis adalah dengan mengerjakan soal cerita. Umumnya untuk dapat menyelesaikan soal cerita siswa harus menggunakan penalaran secara deduktif. Pertama-tama siswa harus mampu mentransfer soal cerita tersebut ke dalam model matematika, selanjutnya dengan konsep-konsep yang sudah dimilikinya siswa akan menyelesaikan model tersebut. Interpretasi dari penyelesaian model matematika inilah yang akhirnya digunakan sebagai jawaban atas soal cerita.

Penelitian ini menggunakan pendekatan Kuantitatif dengan Jenis penelitian eksperimental semu (quasi-experimental research). Penelitian ini dilaksanakan di kelas IV SD Muhammadiyah II kota Bengkulu tahun akademi 2016/2017.

Populasi penelitiannya adalah seluruh siswa kelas IV mata pelajaran IPA SD Muhammadiyah II kota Bengkulu dan diambil dua kelas dengan desain Penelitian Faktorial 2x2.

Teknik pengumpulan data dalam penelitian ini menggunakan Tes Tertulis, yaitu tes awal (pre-test) dan tes akhir (pos-test). Pretes digunakan untuk mengukur kemampuan awal siswa dalam dalam berpikir kritis sebelum diberikan perlakuan terlebih dahulu, sedangkan post test digunakan untuk mengukur kemampuan akhir siswa dalam berpikir kritis setelah diberi perlakuan berupa penggunaan model pembelajaran berpikir induktif dan model induktif kata bergambar. Pretes dan postes ini dilakukan pada kedua eksperimen.

\section{Hasil dan Pembahasan}

Skor kemampuan berpikir kritis siswa pada mata pelajaran IPA SD M II kota Bengkulu setelah diberi perlakuan dengan model Berpikir Induktif dan model Induktif Kata Bergambar, dapat dijelaskan berikut ini.

1. Terdapat perbedaan berpikir kritis siswa antara yang diajar dengan menggunakan bahan ajar LKS mata pelajaran IPA berbasis model pembelajaran berpikir induktif dengan berbasis model Induktif Kata Bergambar

Hasil analisis data penelitian yang diperoleh melalui pengujian hipotesis pertama menunjukkan, bahwa secara keseluruhan model pembelajaran berpikir induktif lebih tinggi dibanding dengan model Induktif kata bergambar. Hal ini sebabkan model berpikir induktif menuntut siswa untuk berusaha secara aktif 
dan kreatif dalam berpikir untuk menjawab permasalahan, baik secara individual maupun secara kelompok.

Sementera model induktif kata bergambar siswa masih terpaku pada gambar yang ditayangkan, sehingga pada pemecahan masalah siswa sering terjebak dengan makna pada gambar dan kurang menuntut siswa untuk berpikir kritis walapun sudah menunjukkan keaktifan siswa secara mandiri maupun kelompok.

Penerapan kedua model pembelajaran, yakni model berpikir induktif dan model induktif kata bergambar meruipakan model pembelajaran yang bias diterapkan adalan pembelajaran IPA di SD, khususnya pada kelas IV keatas, karena kedua model tersebut lebih efektif dan mampu memberikan kemampuan berpikir kritis siswa dibandingkan dengan pembelajaran yang selama ini diterapkan di SD M II yang cenderung siswa dalam menjawab permasalahan atas dasar hafalan, sehingga ketika pertanyaan diputar balik siwa tidak mampu menjawab dengan benar.

Terdapat perbedaan berpikir kritis siswa yang berkemampuan awal tinggi dan rendah antara yang diajar dengan menggunakan bahan ajar LKS mata pelajaran IPA berbasis model pembelajaran berpikir induktif dengan berbasis model Induktif Kata Bergambar.

Hasil analisis data penelitian yang diperoleh melalui pengujian hipotesis kedua dan ketiga menunjukkan bahwa: a) siswa yang berkemampuan awal tinggi diajar dengan menggunakan bahan ajar LKS mata pelajaran IPA berbasis model pembelajaran berpikir induktif (A1B1) berbeda dan lebih tinggi dibanding dengan menggunakan model Induktif Kata Bergambar (A2B1). b) siswa yang berkemampuan awal rendah diajar dengan menggunakan bahan ajar LKS mata pelajaran IPA berbasis model pembelajaran berpikir induktif (A1B2) berbeda dan lebih tinggi dibanding dengan menggunakan model Induktif Kata Bergambar (A2B2)

Penggunaan model berpikir induktif dalam pembelajaran IPA kelas IV SD Muhammadiyah II kota Bengkulu sebagai upaya peningkatan kemampuan berpikir kritis siswa sangat efektif dibanding dengan menggunakan model induktif kata bergambar, terutama bagi siswa yang berkemampuan tinggi, sementara yang berkemampuan rendah kedua model tersebut sama efektifnya dalam peningkatan kemampuan berpikir kritis siswa.

Peningkatan kemampuan berpikir kritis siswa ini dapat dilihata pada tabel berikut ini.

Data di atas menggambarkan bahwa perolehan tes kemampuan awal (pretest) anatara kelompok siswa yang berkemampuan awal tinggi yang diajar dengan model berpikir induktif dengan model induktif kata bergambar tidak jauh berbeda (relative sama), begitu juga kelompok sisw yang berkemampuan rendah. Selanjutnya bila dicermati jelas terlihat, bahwa perolehan skor berpikir kritis siswa (posttest) menunjukkan adanya perbedaan antara kempok siswa yang berkemampuan awal tinggi diajar dengan dengan model berpikir induktif dengan model induktif kata bergambar. Sebaliknya tidak ada perbedaan 
kemampuan berpikir kritis siswa yang berkemampuan awal rendah diajar dengan model berpikir induktif dengan model induktif kata bergambar. Hal ini disebabkan karena dalam pembelajaran dengan model berpikir induktif, Guru bukan mengajarkan apa itu berpikir namun bagaimana siswa berpikir, oleh karena itu guru memerlukan metode yang dapat mengembangkan keterampilan berpikir siswa.

Melalui model pembelajaran tersebut siswa dapat lebih kritis dalam memecahkan permasalahan dalam kehidupan sehari-hari. Sedangkan dalam model induktif kata bergambar berkonsep awal dengan penggunaan gambar sebagai stimulus bagi pengalaman berbahasa, maka aktivitas-aktivitas di ruang kelas perlu dikembangkan untuk diterapkan dalam seni berbahasa, khususnya untuk melatih para pembaca pemula membaca dan menulis dengan baik. Jadi model induktif kata bergambar lebih cocok untu siswa yang berkempuan awal rendah.

3. Interaksi antara model pembelajaran dengan pengetahuan awal terhadap kemampuan berpikir kritis siswa pada mata pelajaran IPA

Berdasarkan hasil uji hipotesis keempat menujukkan adanya interaksi antara model pembelajaran dengan kemampuan awal terhadap kemampuan berpikir kritis siswa pada mata pelajaran IPA. Hal ini dibuktikan dengan adanya perubahan kemampuan berpikir kritis siswa, baik secara keseluruhan maupun dilihat dari masing-masing kemampuan awal yang diajar dengan menggunakan model berpikir induktif dan model induktif kata bergambar.

Hasil analisis of varians (anova) dengan SPSS untuk uji hipoteisis keempat dapat dideskripsikan sebagai berikut :

a. Untuk factor $\mathrm{A}, \mathrm{Fh}>\mathrm{F}$ tabel $(6.532>4.11)$ dan sig $0.18<0.05$, yang berarti terdapat perbedaan kemampuan berpikir siswa antara yang diajar dengan model berpikir induktif dengan model induktif kata bergambar.

b. Untuk factor B (kemampuan awal) menunjukkan adanya perbedaan kemampuan berpikir kritis siswa yang memiliki kemampuan awal $\mathrm{Fh}<$ Ft $(0.028<4.11)$. Jika dilihat dari masing-masing kemampuan awal, maka untuk kemampuan awal tinggi terdapat perbedaan (hipotesis 2), sedangkan untuk kemampuan awal rendah tidak terdapat perbedaan ( hipotesis 3).

c. Faktor Interaksi (AXB). Menolak hipotesis Nol dan menerima hipotesis alternative, yang berarti efek factor model pembelajaran dan kemampuan awal berpengaruh terhadap kemampuan berpikir kritis siswa, atau sebaliknya.

d. Hasil analisis dengan menggunakan Anova dapat dipahami bahwa terjadi interaksi antara model pembelajaran dengan kemampuan awal siswa secara gabungan terhadap kemampuan berpikir kritis siswa pada taraf signifikasi 0.05 dan tidak terjadi interaksi pada taraf signifikansi 0.001 . 
Secara teoritis terjadi dan tidaknya interaksi angtara model pembelajaran dengan kemampuan awal siswa terhadap kemampuan berpikir kritis siswa, karena dua model pembelajaran ini memeliki keunggulan yang berbada dalam penggunaannya. Baik secara keseluruhan maupun secara parsial dilihat dari kemampuan awal tinggi dan rendah.

\section{Penutup}

Berdasarkan analisa data dan pembahasan hasol penelitian tentang Perbedaan berpikir kritis antara siswa yang diajar dengan Menggunakan Model Berpikir Induktif dan model induktif Kata bergambar pada Mata Pelajaran IPA Kelas IV SDM II Kota Bengkulu, maka dapat disimpulkan:

1. Secara keseluruhan terdapat perbedaan berpikir kritis siswa antara yang diajar dengan menggunakan bahan ajar LKS mata pelajaran IPA berbasis model pembelajaran berpikir induktif dengan berbasis model Induktif Kata Bergambar. Hal ini dibuktikan dengan uji-t diperoleh nilai-t 2.461 dengan df 38 dan Sig. 0,018 (2-tailed). Nilai Sig. (2-tailed) sebesar 0,018 lebih kecil dari taraf signifikasi 5\% (0,050) .

2. terdapat perbedaan berpikir kritis siswa yang berkemampuan awal tinggi antara yang diajar dengan menggunakan bahan ajar LKS mata pelajaran IPA berbasis model pembelajaran berpikir induktif dengan berbasis model Induktif Kata Bergambar. Hal ini dibuktikan dengan uji-t diperoleh nilai-t 4.935 dengan df 18 dan Sig. (2-tailed) 0.00. Nilai Sig. (2-tailed) yang sebesar $0 . .00$ lebih kecil dari taraf signifikasi 5\% $(0,050)$.

3. tidak terdapat perbedaan berpikir kritis siswa yang berkemampuan awal rendah antara yang diajar dengan menggunakan bahan ajar LKS mata pelajaran IPA berbasis model pembelajaran berpikir induktif dengan berbasis model Induktif Kata Bergambar. Hal ini dibuktikan dengan ujit diperoleh nilai-t 0.190 dengan df 18 dan Sig. (2-tailed) 0.500 . Nilai Sig. (2-tailed) yang sebesar 0.500 lebih besar dari taraf signifikasi 5\% (0,050) .

4. Terdapat interaksi antara model pembelajaran dengan pengetahuan awal terhadap kemampuan berpikir kritis siswa pada mata pelajaran IPA di SD Muhammadiyah II kota Bengkulu. Hal ini dibuktikan dengan uji F melalui SPSS , bahwa hasil Fh sebesar 4.946 dengan nilai Sig. (2tailed $)=0.033<(0,050)$ menyatakan bahwa. Secara signifikan diterima.

Walaupun ada perbedaan efektifitas penggunaan kedua model dalam meningklatkan kemampuan berpikir kritis siswa pada mata pelajaran IPA, namun pada dasarnya kedua model tersebut dapat digunakan dalam penerapan pembelajaran IPA di SD. 


\section{Daftar Pustaka}

Al-Qur'an dan Terjemahan

Agus Suprijono. 2014. Cooperative Learning, Yogyakarta: Pustaka Belajar.

Ahmad Susanto. 2013. Teori Belajar Pembelajaran di Sekolah Dasar, Jakarta: Kencana.

Anas Sudijono. 2011. Pengantar Statistik Pendidikan, Jakarta: Raja Grafindo Persada.

Arief Furchan. 2004. Pengantar Penelitian Dalam Pendidikan, Yogyakarta: Pustaka Pelajar.

Bruce,J,Marsha,W dan Emily. 2009. Models Of Teaching. Yogyakarta: Pustaka Pelajar

Burhan Nurgianto, dkk., 2009. Statistik. Terapan Untuk Penelitian Ilmu-Imu Sosial, Yogyakarta: Gadjah Mada.

Daryanto. 2014. Pembelajaran Tematik, Terpadu, Terintegrasi (Kurikulum 2013). Yogyakarta: Gava Media

Depdiknas. 2003. Undang-Undang Nomor 20 Tabun 2003 tentang sistem Pendidikan Nasional, Jakarta: Depdiknas.

Dimyati dan Mujiono. 2006. Belajar dan Pembelajaran, Jakarta: Rineka Cipta.

Dwi Murwani, Elika. 2006. "Peran Guru dalam Membangun Kesadaran Kritis siswa” Jurnal Pendidikan Penabur Rosdakarya.

E. Mulyasa. 2009. Kurikulum Tingkat Satuan Pendidikan, Bandung: Remaja

Etin Solihatin dan Raharjo. 2009. Cooperative Learning Analisis Pembelajaran IPS. Jakarta: Bumi Aksara.

Hamzah, B. 2009. Model Pembelajaran Menciptakan Proses Belajar Mengajar Yang Kreatif dan Efektif. Jakarta: Bumi Aksara.

Imas Kurniasih dan Berlin Sani. 2015. Ragam Pengembangan Model Pembelajaran Untuk Peningkatan Profesionalitas Guru, Kata Pena.

Irwan Satria. 2015. Konsep Dasar dan Pendidikan Ilmu Pengetabuan Sosial, Bogor: IPB Press.

John M. Echols dan Hassan Shadily. 2003. Kamus Inggris Indonesia, Jakarta: Gramedia Pustaka Utama.

Karli, Hilda. 2012. Model Pembelajaran Untuk Mengembangkan Keterampilan Berpikir. Jurnal Pendidikan Penabur. Bandung

Kowiyah. 2012. Kemampuan Berpikir Kritis. Jurnal Pendidikan Dasar

Kunandar. 2010. Guru Profesional Implementasi Kurikulum Tingkat Satuan Pendidikan (KTSP) dan Sukses dalam Sertifikasi Guru, Jakarta: Rajawali Pers.

MB. Rahimsyah dan Satyo Adhie. 2013. Kamus Lengkap Babasa Indonesia, Jakarta: Aprindo.

Mel Silberman L. 2007. Active Learning: 101 Strategi Pembelajaran Aktif, Yogyakarta: Insan Madani.

Mulyasa, E. 2009. KTSP. Bandung: Remaja Rosdakarya. 
Nana Sudjana. 2010. Penilaian Hasil Belajar Mengajar, Bandung: Remaja Rosdakarya.

Riduwan. 2010. Dasar-Dasar Statistika, Bandung: Alfabeta.

Sugiyono. 2011. Penelitian Kualitatif Kuantitatif dan R\&D, Bandung: Alfabeta.

Sugiyono.2010. Metode Penelitian Pendidikan, Bandung: Alfabeta.

Suharsimi Arikunto. 2006. Prosedur Penelitian Suatu Pendekatan Praktik, Jakarta: Rineka Cipta.

Sulistyorini, Sri. 2007. Model Pembelajaran IPA Sekolab Dasar dan Penerapannya Dalam KTSP. Yogyakarta: Tiara Wacana

Rusman. 2013. Model-Model Pembelajaran, Jakarta: PT Raja Grafindo.

Syah Muhibbin. 2003. Psikologi Belajar, Jakarta: RajaGrafindo.

Syaiful Bahri Djamarah dan Aswan Zain. 2010. Strategi Belajar Mengajar, Jakarta: Rineka Cipta. 